\title{
Characterization of Native and Oxidized Starches of Two Varieties of Peruvian Carrot (Arracacia xanthorrhiza, B.) From Two Production Areas of Paraná State, Brazil
}

\author{
Luciana Shizue Matsuguma ${ }^{1}$, Luiz Gustavo Lacerda ${ }^{1}$, Egon Schnitzler ${ }^{1}$, Marco Aurélio da \\ Silva Carvalho Filho ${ }^{2}$, Célia Maria Landi Franco ${ }^{3}$ and Ivo Mottin Demiate ${ }^{1^{*}}$ \\ ${ }^{I}$ Universidade Estadual de Ponta Grossa; Av. General Carlos Cavalcanti, 4748; 84030-900; Ponta Grossa - PR - \\ Brasil. ${ }^{2}$ Universidade Positivo; Rua Prof. Pedro Viriato Parigot de Souza, 530; 81280-330; Curitiba - PR - Brasil. \\ ${ }^{3}$ Departamento de Engenharia e Tecnologia de Alimentos; Instituto de Biociências, Letras e Ciências Exatas; \\ Universidade Estadual Paulista Júlio de Mesquita Filho; Rua Cristóvão Colombo, 2265; 15054-000; São José do \\ Rio Preto - SP - Brasil
}

\begin{abstract}
Two commercial varieties of Peruvian carrot ('Amarela de Carandaî' and 'Senador Amaral') were processed into flour, starch and bagasse and chemically evaluated. The starch was extracted, modified with $\mathrm{H}_{2} \mathrm{O}_{2}$ and characterized by the physicochemical methods. By using the methylene blue dyeing, the granules of the modified starches showed intense blue color. The carboxyl content, the reducing power and the amount of the water liberated from the pastes after the freeze-thawing were higher for the oxidized starches and their pastes were clearer than those of the native starches of the two varieties from the two production areas. The RVA viscoamylography showed that the modified starches had lower viscosities with differences between the varieties. In the thermal analysis, the temperatures of the pyrolysis were higher for the native $\left(310.37,299.08,311.18{ }^{\circ} \mathrm{C}\right)$ than for the modified starches (294.16, 296.65 e $\left.293.29^{\circ} \mathrm{C}\right)$ for both the varieties. This difference could be related with the larger surface of the granules due to the partial degradation promoted by the chemical modification. In almost all results, the differences were evident between the varieties but not for the cultivation places.
\end{abstract}

Key words: Peruvian carrot varieties, starch, hydrogen peroxide, technological properties

\section{INTRODUCTION}

Starch is the main source of the carbohydrates in the human diet due to its abundance in the nature. Starch granules are made of glucose polymers, named amylose and amylopectin and found inside the vegetable cells from where they are extracted for the industrial applications by the food, textile and pulp and paper industry. The selection of the starch for the industrial uses is made considering its availability and also its physicochemical characteristics that vary depending on the source. Due to this, each natural or native starch is considered unique. As the industry demands for new technological properties, several nonconventional starch sources were studied in the last years, including the Peruvian carrot (Arracacia xanthorrhiza, Bancroft). Peruvian carrot is a tuberous crop brought from the Colombian Andes to Brazil in the early 1900 and

\footnotetext{
* Author for correspondence: demiate@yahoo.com
} 
its cultivation is concentrated in the Southern region where the climate is favorable. In Brazil, this crop is known as mandioquinha, mandioquinha-salsa, batata-baroa or batata-salsa (Câmara and Santos, 2002). As the South American tuberous crops are relatively less studied for the commercial starch production, Brazil has a great opportunity of becoming an important global player in the new starch market that is searching for the natural products with different properties from the common starches, i.e., corn, wheat and potato, that are produced in the large scale by the developed countries (Leonel and Cereda, 2002). In order to increase the industrial applications, the starches are modified by the physical, chemical or enzymatic treatments. The oxidation results in partially converted or degraded starches that are able to produce the high fluidity pastes at high solids concentration, being classified as thinboiling starches. Hydrogen peroxide is one of the reagents employed to produce the oxidized starches and the reactions that occur during the starch modification are described as very complex (Parovuori et al., 1995). The oxidized starch has been widely used in many industries, particularly for the paper, textile, laundry finishing, and building materials industries to provide surface sizing and coating properties. The oxidized starch is also becoming increasingly important in the food industry for its unique functional properties such as low viscosity, high stability, clarity, film forming, and binding properties. This can be used as a coating and sealing agent in the confectionary, as an emulsifier, as a dough conditioner for the bread, as a gum arabic replacer, and as a binding agent in the batter applications (Wang and Kuakpetoon, 2006). The characterization of new starches from the alternative sources was the objective of this work that also included the production of the oxidized starch and the evaluation of its physicochemical properties.

\section{MATERIALS AND METHODS}

\section{Materials}

In this work, two varieties of Peruvian carrot from the two cities (Castro and Piraí do Sul) from the Campos Gerais region of the Paraná State (Brazil) were evaluated. The variety 'Amarela de Carandaí' was collected from Castro (ACC) and from Piraí do Sul (ACP) and the variety 'Senador Amaral' only from Piraí do Sul (SAP). All the roots were harvested in August 2004, around one year after planting. The soils where the roots were produced were rich in clay and chemical fertilizers were provided with phosphorous and potassium chloride, using the vegetative multiplication. The reagents used for the analyses of the fractions (flour, starch and bagasse) were of analytical grade. Commercially available industrial enzymes, a thermostable alpha-amylase (Termamyl ${ }^{\circledR}$ ) and an amyloglucosidase $\left(\mathrm{AMG}^{\circledR}\right)$, both from Novozymes (Araucária, PR, Brazil), were also employed.

\section{Samples}

The Peruvian carrot starch was obtained as described by Peroni (2003) that extracted the cassava starch, with some adaptations. Cold water (around $5{ }^{\circ} \mathrm{C}$ ) was employed in order to minimize the enzymatic browning as well as the microbial growth. The extracted starch and the resulting bagasse were oven-dried and their chemical composition was evaluated.

\section{Chemical modification by oxidative treatment}

The starches were modified by the reaction with hydrogen peroxide as described by Parovuori et al. (1995). The concentration of hydrogen peroxide was initially checked on the reagent. As catalyzer a $0.01 \% \mathrm{FeSO}_{4}$ solution was used and the $\mathrm{pH}$ was corrected to 3.0; then, starch was added and kept in the suspension by mechanical stirring. Hydrogen peroxide was added to the starch suspension to a final concentration of $1.25 \%$ and the reaction occurred at $20{ }^{\circ} \mathrm{C}$ for 15 minutes. After this period, the starch was recovered, washed and oven-dried at $45^{\circ} \mathrm{C}$ for $24 \mathrm{~h}$.

\section{Chemical characterization}

The moisture, lipid, protein and mineral residue contents were analysed as described on AOAC (1994). Total carbohydrates were calculated as difference.

\section{Fiber}

The fiber content was determined and then the starch analysis was made, employing the dietary fiber method (AOAC, 1997) with some modifications. At first, a dialysis was made to eliminate the low molecular weight components $(<14,000 \mathrm{Da})$ and only the material that was retained in the dialysis bag was hydrolyzed (Demiate et al., 2001). After the enzymatic hydrolysis, a fraction was collected for the starch analysis. The remaining material was weighed, 
filtered and washed with 78 and $92{ }^{\circ} \mathrm{GL}$ ethanol and acetone in $a \mathrm{n}^{\circ} 2$ filter crucible that was dried in the oven at $105{ }^{\circ} \mathrm{C}$ for $24 \mathrm{~h}$. The mineral residue and protein content were measured and subtracted from the total dry weight and then the fiber content was calculated.

\section{Starch content}

The starch contents of the milled dry roots, bagasse and starch were determined after the dialysis against the tap water (Demiate et al., 2001). After this, the samples were hydrolyzed with Termamyl ${ }^{\circledR}$ and $\mathrm{AMG}^{\circledR}$ and then a glucose oxidase kit was used for quantifying the glucose and the starch content was calculated (Dahlquist, 1961). Blanks were made with the commercial enzyme preparations for allowing the starch determination.

\section{Differential dyeing and microscopy of starch granules}

The starch granules were observed by the light microscopy after being dyed with the methylene blue (Christianson et al., 1969; Snyder, 1984) for the qualitative information about the negative charges of the carboxyl groups. The samples (around $100 \mathrm{mg}$ ) were suspended in $25 \mathrm{~mL} 0.1 \%$ methylene blue and stirred for 10 minutes. After this, the samples were exhaustively washed and recovered by centrifugation, dried at $45^{\circ} \mathrm{C}$ for 24 $\mathrm{h}$ and observed with an Olympus BX41 light microscope, and photographed with a 5.1 megapixel digital camera (C 5060 ADU).

\section{Carboxyl content}

The carboxyl content of the starches was evaluated as described by Smith (1967) and employed by Parovuori et al. (1995). With the objective of acidifying the carboxyl groups of the samples, 500 $\mathrm{mg}$ of starch was suspended in $30 \mathrm{~mL}$ of $0.1 \mathrm{~mol}$ $\mathrm{L}^{-1} \mathrm{HCl}$ for 30 minutes at room temperature (around $20^{\circ} \mathrm{C}$ ) and maintained under the magnetic stirring. After this, the starch was exhaustively washed and recovered by centrifugation $(2,000 \mathrm{~g})$ until the $\mathrm{pH}$ raised close to neutrality. This procedure was named de-mineralization by Smith (1967). The starch was then quantitatively transferred to an Erlenmeyer flask and dispersed in $300 \mathrm{~mL}$ of deionized water. This suspension was heated at $97.5{ }^{\circ} \mathrm{C}$ under agitation to promote the complete starch gelatinization. The hot starch solutions were titrated with $0.002 \mathrm{~mol} \mathrm{~L}^{-1} \mathrm{NaOH}$ until $\mathrm{pH}$ 8.3, using the phenolphthalein as indicator. The results represented the carboxyl content of the starch samples, but could include the fatty acids complexed with the starch (Mattisson and Legendre, 1952). The carboxyl content was calculated by the Equation 1:

$\% \mathbf{C O O H}=\mathrm{mL}$ of $\mathrm{NaOH}$ spent with the sample $\mathrm{x}$ $\mathrm{mol} / \mathrm{L}$ of the $\mathrm{NaOH} \times 0.045 \times 100 / \mathrm{g}$ dry sample. (Eq. 1)

\section{Reducing power}

The reducing power (RP) was measured as the reduction of ferric to ferrous cyanide by the starch, with the generation of a precipitate. The ferric ions in excess reduced the iodine which was titrated with the thiosulphate. The RP was calculated by the Eq. 2 (International Starch Institute, 2005).

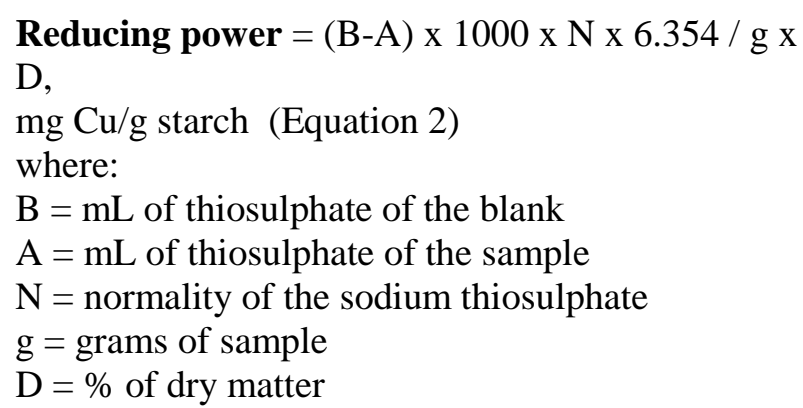

\section{Swelling power and solubility}

The swelling power and solubility of the starches were evaluated as described by Leach et al. (1959), with few modifications. The samples were weighed $(0.2 \mathrm{~g}$, wet basis) in tared centrifuge tubes and $18 \mathrm{~g}$ of the deionized water were added. The suspension was agitated and immersed in a water bath with agitation for 30 minutes at 65 to $85^{\circ} \mathrm{C}$. After this, the external walls of the tubes were dried with the absorbing paper and the tubes were completed to $20 \mathrm{~g}$ with the deionized water. The tubes were closed, homogenized and submitted to a 3,400 rpm centrifugation $(2,000 \mathrm{~g})$ for 15 minutes. An aliquot of $5 \mathrm{~mL}$ of the supernatant was taken and dried in an oven at $105^{\circ} \mathrm{C}$ for $24 \mathrm{~h}$ for determining the solubility. The resulting pellet was weighed and the swelling power and solubility was calculated by the Equations 3 and 4:

\% Solubility = soluble starch weight $\times 400 /$

Swelling power $=$ pellet weight $\times 100$

sample weight (dry basis) x (100 - \% solubility) (Eq. 4) 


\section{Apparent viscosity}

Starch apparent viscosity was evaluated by using a Rapid Viscoanalyzer (RVA 4, Newport Scientific, Narabeen, Australia). The samples (2 g of dry matter) were suspended in $28 \mathrm{~g}$ of the deionized water and $0.2 \mathrm{~mol} / \mathrm{L}$ acetate and phosphate buffers, with $\mathrm{pH}$ values of 4.0 and 7.0, respectively. The suspensions were homogenized in the aluminum canister of the RVA, equilibrated at $50{ }^{\circ} \mathrm{C}$ for two minutes and heated to $95{ }^{\circ} \mathrm{C}$ at a $6{ }^{\circ} \mathrm{C} /$ minute rate and kept at this temperature for five minutes. After this, the samples were cooled to $50{ }^{\circ} \mathrm{C}$ at the same $6{ }^{\circ} \mathrm{C} /$ minute rate. From the collected viscoamylograms, the main points of the interest were the pasting temperature $\left({ }^{\circ} \mathrm{C}\right)$, viscosity peak (RVU), setback (RVU), break (RVU) and final viscosity (RVU). The apparent viscosity evaluated by the RVA was measured in the empiric RV units (Demiate et al, 2005; Franco et al., 2002).

\section{Syneresis}

The starch samples were suspended in the deionized water $(8 \%, w / w)$, gelatinized and kept boiling $\left(97.5^{\circ} \mathrm{C}\right)$ under agitation for 10 minutes. The paste was divided in three portions of $50 \mathrm{~g}$ and frozen at $-18{ }^{\circ} \mathrm{C}$ in the hermetic plastic cups. The pastes were submitted to three freeze-thaw cycles, being kept into the freezer for $72 \mathrm{~h}$ and thawed at $45{ }^{\circ} \mathrm{C}$ for three hours (Wosiacki and Cereda, 1985; Demiate et al., 2001). The amount of the water liberated from the pastes under the reduced pressure $(-490 \mathrm{mmHg})$ was measured gravimetrically after thawing and expressed as the liberated water in relation to the initial weight.

\section{Paste Clarity}

The paste clarity was evaluated by determining the percentage of the transmittance $(\% \mathrm{~T})$ of $1 \%$ starch pastes, as described by Craig et al. (1989). The starch suspension was heated for 30 minutes in a boiling water bath $\left(97.5^{\circ} \mathrm{C}\right)$, with agitation to ensure complete pasting. After cooling to the room temperature (around $20{ }^{\circ} \mathrm{C}$ ), the transmittance of the pastes was measured at $650 \mathrm{~nm}$, using a FEMTO model 432 spectrophotometer (Femto, São Paulo, Brazil).

\section{Thermal analysis}

The thermal analyses were performed on a Shimadzu TG-DTA model TG-60 (Shimadzu, Kyoto, Japan). The analyses were run in a synthetic air atmosphere at a flow rate of 100 $\mathrm{mL} / \mathrm{min}$. in the opened alumina crucibles containing around five milligrams of starch at a heating rate of $10^{\circ} \mathrm{C} / \mathrm{min}$. The analyses started at $30^{\circ} \mathrm{C}$ and the final temperature was $600{ }^{\circ} \mathrm{C}$.

\section{RESULTS AND DISCUSSION}

\section{Peruvian carrot starch extraction}

Although evaluating the starch extraction yield was not an objective of this work, the data were obtained (Table 1) only for the comparison between the varieties (ACC - Amarela de Carandaí/Castro, ACP - Amarela de Carandaí/Piraí do Sul and SAP - Senador Amaral/Piraí do Sul). Starch extraction was made in the laboratory and the material was dried in the oven.

Table 1 - Peruvian carrot starch extraction.

\begin{tabular}{ccccc}
\hline Sample & Root weight $^{1} \mathbf{( k g )}$ & Bagasse weight $^{2} \mathbf{( k g )}$ & Starch weight $^{3}(\mathbf{k g})$ & Yield $(\%)^{(\%)}$ \\
\hline$A C C$ & 24.346 & 1.579 & 2.510 & 10.30 \\
$A C P$ & 14.574 & 0.858 & 1.007 & 6.91 \\
$S A P$ & 10.564 & 1.052 & 0.892 & 8.52 \\
\hline
\end{tabular}

The starch of Peruvian carrot is not commercially available and there are few scientific papers about its physicochemical properties. As cited by Bermudez (1997), the extraction technology has great influence on starch yield. Although Hurtado et al. (1997) related the theoretical yields of up to $20-30 \mathrm{~g} / 100 \mathrm{~g}$, in the laboratory extraction only 6 to $13 \mathrm{~g} / 100 \mathrm{~g}$ were obtained. Pereira (1997), considering the nutritional value of Peruvian carrot, described the starch content of the roots as $23 \mathrm{~g} / 100 \mathrm{~g}$. As the starch granules dimensions influence its extraction and purification as well as its functional properties, it is very important to know these characteristics. Vieira (2004) evaluated the Peruvian carrot starch granules dimensions and found the diameters between 3.2 and $26.4 \mu \mathrm{m}$ to 4.1 and $29.7 \mu \mathrm{m}$. 
Chemical composition of the roots, bagasse and starch of the varieties of Peruvian carrot

The results of the chemical composition of the roots are presented in Table 2 and are in accordance with that of Pereira (1997). The chemical composition had differences between the regions as well as between the varieties, which suggested that both the genetic and agronomic factors influenced them.

\section{Carboxyl content}

There are several types of the oxidized starches, produced by the treatment with hypochlorite, peroxide, UV radiation, that could present the carboxyl groups in their macromolecules (Cereda et al., 2003). The carboxyl contents of the starches are shown in Table 3, expressed as $\mathrm{COOH} / 100 \mathrm{~g}$ of the starch.

Table 2 - Chemical composition of the roots, bagasse and starch of Peruvian carrot.****

\begin{tabular}{lccccccccc}
\hline & \multicolumn{3}{c}{ ACC } & \multicolumn{3}{c}{ ACP } & \multicolumn{2}{c}{ SAP } \\
\cline { 2 - 9 } & Root & Bagasse & Starch & Root & Bagasse & Starch & Root & Bagasse & Starch \\
\hline Ash (\%)** & $4.23 \pm 0.04$ & $1.62 \pm 0.01$ & $0.08 \pm 0.02$ & $4.34 \pm 0.05$ & $1.44 \pm 0.05$ & $0.31 \pm 0.01$ & $4.85 \pm 0.02$ & $1.83 \pm 0.06$ & $0.05 \pm 0.02$ \\
Protein (\%)** & $4.69 \pm 0.05$ & $1.83 \pm 0.02$ & $0.14 \pm 0.03$ & $4.18 \pm 0.04$ & $2.10 \pm 0.06$ & $0.26 \pm 0.07$ & $6.11 \pm 0.12$ & $2.52 \pm 0.27$ & $0.20 \pm 0.03$ \\
Total & & & & & & & & & \\
carbohydrate* & 82.2 & 76.2 & 99.4 & 80.3 & 81.8 & 99.0 & 77.5 & 75.3 & 99.3 \\
Starch (\%)*** & 82.2 & 67.6 & 98.7 & 80.3 & 68.2 & 97.6 & 77.5 & 69.2 & 98.5 \\
Lipid (\%) & $1.39 \pm 0.02$ & $0.73 \pm 0.01$ & $0.39 \pm 0.01$ & $1.05 \pm 0.01$ & $0.65 \pm 0.01$ & $0.40 \pm 0.01$ & $0.61 \pm 0.03$ & $0.30 \pm 0$ & $0.42 \pm 0$ \\
Fiber (\%)*** & 9.17 & 19.5 & 0 & 10.8 & 14.0 & 0 & 10.9 & 20.1 & 0 \\
\hline Moisture (\%)** & $73.2 \pm 0.01$ & $6.25 \pm 0.02$ & $8.70 \pm 0.02$ & $74.5 \pm 0.03$ & $6.85 \pm 0.05$ & $10.0 \pm 0.02$ & $69.9 \pm 0.01$ & $7.8 \pm 0.01$ & $6.86 \pm 0.02$ \\
\hline$*$ calculated by difference; ** each value represents the average and standard deviation of three repetitions; ***the values \\
without deviation were obtained without repetition **** values expressed on dry basis.
\end{tabular}

Table 3 - Carboxyl content of Peruvian carrot starches.

\begin{tabular}{cc}
\hline Sample & Carboxyl \% $(\mathbf{w} / \mathbf{w})^{*}$ \\
\hline$A C C-$ native & $0.21 \pm 0.01$ \\
$A C C-$ modified & $0.29 \pm 0.02$ \\
$A C P$ - native & $0.18 \pm 0.01$ \\
$A C P$ - modified & $0.34 \pm 0.04$ \\
$S A P-$ native & $0.19 \pm 0.01$ \\
$S A P-$ modified & $0.33 \pm 0.02$ \\
\hline
\end{tabular}

*each value represents the average and the deviation of three repetitions; values presented in wet basis.

Evidently, the modified starches have higher carboxyl contents when compared with the native ones. The carboxyl groups are formed during the oxidative modification of the starch macromolecules that also causes increase in the reducing value due to the partial fragmentation of the polymers. Although the oxidized starches had higher values than the native ones, as these values were low, was showing the differences from the literature, mentioning that the oxidized starches should have high carboxyl contents (up to $1 \%$ ), produce low viscosity pastes, have lower molecular weight than the respective native starches and have low tendency to retrogradation due to sterical hindrance promoted by the large carboxyl groups that substituted some hydroxyl (Daiuto, 2005).

\section{Reducing power}

Table 4 shows the reducing power of the native and modified starches. The highest values were observed for the starches modified by the hydrogen peroxide treatment. The increase in the reducing value could be explained by the partial degradation of the polysaccharides during the oxidation reaction. There was formation of smaller macromolecules than the original with the consequent increase in the concentration of the 
reducing ends. As reviewed by Dias (2001), the oxidation of the starch involves the conversion of hydroxyl groups of the non-reducing ends of the macromolecules to carboxyl groups, ketone or aldehyde and of the aldehyde groups of the terminal reducing end of the starch in carboxyl.

Table 4 - Reducing power (RP, mg Cu/g starch) of the samples.

\begin{tabular}{cc}
\hline Sample & RP $(\mathbf{m g C u} / \mathbf{g})^{*}$ \\
\hline$A C C-$ modified & $47.4 \pm 9.60$ \\
$A C C-$ native & $23.5 \pm 0.42$ \\
$A C P-$ modified & $60.8 \pm 1.08$ \\
$A C P$ - native & $49.4 \pm 5.71$ \\
$S A P-$ modified & $73.4 \pm 0.37$ \\
$S A P$ - native & $28.2 \pm 3.50$ \\
\hline
\end{tabular}

* each value is the average and the deviation of three repetitions; values are expressed on dry basis.

\section{Differential dyeing and microscopy of the granules}

The intensity of the dyeing is an indicator of the density of the charge in the starch granules (Christianson et al., 1969). The results (pictures not shown) allowed the observation of more intense blue color for the modified starches that had more carboxyl groups as confirmed by the carboxyl analysis. Demiate (1999) studied the native and potassium permanganate/lactic acidmodified cassava starch and detected intense blue color on the starch when modified by the oxidative reagent and only light blue color on the native starch. It is well established that the hydroxyl groups of the starch result on a weak anionic character. Charged starches, due to some types of the chemical modifications, have high affinity for the ionic dyes. The oxidized starches present an anionic character and the intensity of the dyeing can be associated to the level of chemical modification.

\section{Swelling power and solubility}

The results of these analyses depend on the total gelatinization of the starch granules that must be carried out in the excess of water, allowing the free and complete swelling of the granules (Ciacco et al., 1982). The results of the swelling power and solubility at 65,75 and $85^{\circ} \mathrm{C}$ of the native starches are presented on Table 5. In the case of the modified starches, it was not possible to measure the swelling power and solubility due to the fact that the samples produced very fluid and transparent pastes as described by Takizawa et al. (2004) who studied the starches modified by the potassium permanganate and lactic acid. Considering the molecular level, many factors affect the degree of association, composition and distribution of the crystalline zones; the ratio amylose/amylopectin, their average molecular weight, degree of branching of the chains, conformation and length of the external chains of the amylopectin fraction (Asaoka et al., 1992; Leach et al, 1959). As related by Hashim et al. (1992), during the gelatinization the starch granules have a limited swelling and only a small proportion of the carbohydrates is solubilized but at $90{ }^{\circ} \mathrm{C}$, both the swelling and solubilization degrees increase. The solubility of the starch granules is more related with the amylose fraction that leaks from the granules. As shown in Table 5, the starches became more soluble at higher temperatures (important for food applications of starch). Many easy-to-cook processed foods that have high contents of starch, such as the soups, puddings and creams are based on high solubility heat-treated starches. These starches, due to previous cooking, are named pre-gelatinized and when added to the foods, make their preparation very easy and quick (Ciacco et al., 1982). 
Table 5 - Swelling power (SP) and solubility $(\% \mathrm{~S})$ of the Peruvian carrot native starches.

\begin{tabular}{|c|c|c|c|c|c|c|}
\hline \multirow[t]{2}{*}{ Samples } & \multicolumn{2}{|c|}{$65^{\circ} \mathrm{C}$} & \multicolumn{2}{|c|}{$7^{\circ} \mathrm{C}$} & \multicolumn{2}{|c|}{$85^{\circ} \mathrm{C}$} \\
\hline & SP (times) & $\% \mathrm{~S}$ & SP (times) & $\% \mathrm{~S}$ & SP (times) & $\% \mathrm{~S}$ \\
\hline$A C C$ & $16.1 \pm 1.58$ & $10.4 \pm 5.39$ & $21.4 \pm 0.74$ & $16.9 \pm 6.97$ & $56.9 \pm 4.12$ & $82.8 \pm 10.9$ \\
\hline$A C P$ & $14.5 \pm 1.91$ & $9.60 \pm 0.48$ & $18.9 \pm 0.72$ & $18.1 \pm 1.33$ & $35.4 \pm 2.64$ & $39.2 \pm 0.28$ \\
\hline$S A P$ & $21.0 \pm 4.61$ & $10.4 \pm 3.15$ & $26.5 \pm 0.54$ & $30.1 \pm 10.4$ & $50.5 \pm 0.80$ & $80.8 \pm 6.39$ \\
\hline
\end{tabular}

* each value is the average and the deviation of three repetitions; values are expressed on dry basis

\section{Apparent viscosity}

As discussed by Jane et al. (1999), the paste properties of the starches are affected by amylose, lipid and phosphorous contents as well as by the distribution of the length of the amylopectin side chains. Amylopectin favours the granule swelling and pasting whereas amylose and lipids inhibit. Figures 1 to 3 show the RVA viscoamylograms of the native and modified starches, considering the distilled water, $\mathrm{pH} 4.0$ acetate buffer and $\mathrm{pH} 7.0$ phosphate buffer as the solvents. The influence of the $\mathrm{pH}$ was pronounced on the modified starches. The native Peruvian carrot starches had an average viscosity peak of $432 \mathrm{RVU}$. When the native starches were pasted at $\mathrm{pH} 4.0$ acetate buffer, their viscosity peaks were very close to that found for the analyses in the distilled water but when the analyses were made with $\mathrm{pH} 7.0$ phosphate buffer, the viscosity peaks were higher. These results showed that in more acidic environment, the native starches had lower viscosity peaks than in the neutral $\mathrm{pH}$ values. The viscosity peaks in the distilled water of the native starches from the variety Amarela de Carandaí from Castro (Fig. 1) and from Piraí do Sul (Fig. 2) were of 400 and 391 RVU, respectively, and that of the Senador Amaral was of $504 \mathrm{RVU}$. The modified starch of the variety Senador Amaral from Piraí do Sul (Fig. 3) had a drop in the viscosity peak that was of $175 \mathrm{RVU}$, when analyzed in the distilled water. This was the lowest viscosity peak among the samples and should be related with other results for this starch that presented high carboxyl content $(0.33 \%)$ and the higher reducing power value (73.4 $\mathrm{mg} \mathrm{Cu} / \mathrm{g}$ of starch). When this sample was analyzed at $\mathrm{pH} 7.0$ buffer, its peak viscosity was close to zero (4 RVU). For the other samples, ACC and ACP, the viscosity peaks of the modified starches were of 304 and 359 RVU, respectively.

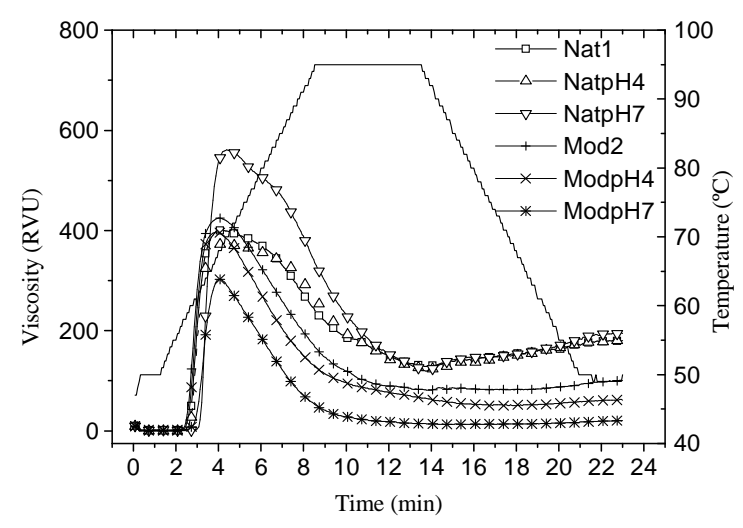

Figure 1 - RVA viscoamylogram of native and modified starches from the variety Amarela de Carandaí/Castro. * Nat1: native starch; NatpH4: native in $\mathrm{pH} 4.0$ buffer; NatpH7: native in $\mathrm{pH} 7.0$ buffer; Mod2: modified starch; ModpH4: modified in $\mathrm{pH} 4.0$ buffer; ModpH7: modified in $\mathrm{pH} 7.0$ buffer. 


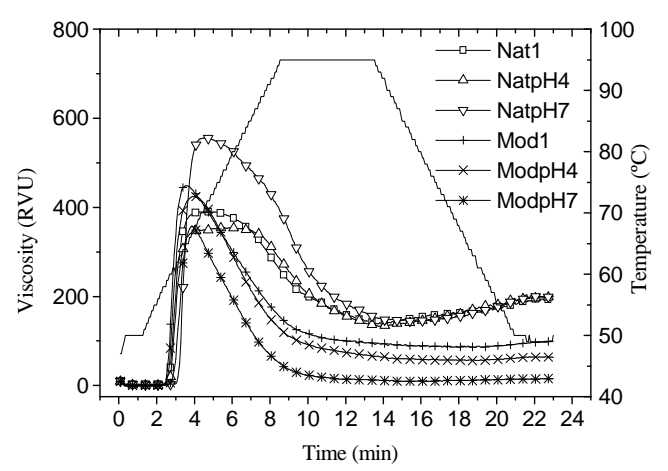

Figure 2 - RVA viscoamylogram of native and modified starches from the variety Amarela de CarandaílPiraí do Sul. *Nat1: native starch; NatpH4: native in $\mathrm{pH} 4.0$ buffer; NatpH7: native in pH 7.0 buffer; Mod1: modified starch; ModpH4: modified in $\mathrm{pH}$ 4.0 buffer; ModpH7: modified in $\mathrm{pH} 7.0$ buffer.

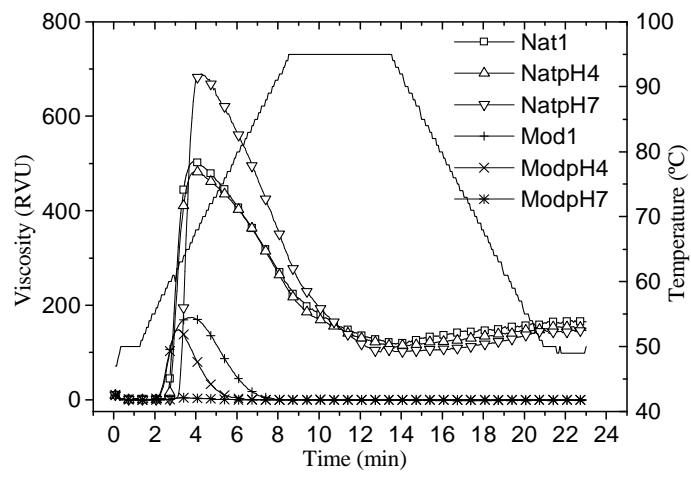

Figure 3 - RVA viscoamylogram of native and modified starches from the variety Senador Amaral/Piraí do Sul.* Nat1: native starch; NatpH4: native in pH 4.0 buffer; NatpH7: native in pH 7.0 buffer; Mod1: modified starch; ModpH4: modified in pH 4.0 buffer; ModpH7: modified in $\mathrm{pH} 7.0$ buffer.

It is well stated that the modification of the starches by the oxidative treatments causes partial degradation of the macromolecules as well as carboxyl groups' introduction in the starch structure (Muhrbeck and Wischmann, 1998). All the oxidized samples had lower pasting temperatures (from 57.2 to $61.9{ }^{\circ} \mathrm{C}$ ) than their respective native counterparts (from 59.1 to 62.5 ${ }^{\circ} \mathrm{C}$ ). When cooked under the agitation, during the viscoamylogram analysis, both the native and modified starches were unstable and their viscosities decreased quickly after the peak. The Peruvian carrot starch is known for its low pasting temperature and this characteristic is very favorable for some food uses as in pre-cooked noodles, soups and puddings. Peroni (2003) stated that the amylose level and the paste properties could make Peruvian carrot starch very useful for the special diets for the infants and old people; this starch could cook very easily with limited retrogradation.

The native starches in all the solvents had higher tendency to retrogradation (from 40 to 72 RVU) than the modified ones ( 0.7 to $21 \mathrm{RVU})$. In the specific conditions of the RVA analysis, this lower retrogradation tendency of the modified starches should be explained by the presence of carboxyl groups and also by the molecular degradation due to the chemical modification. The viscosity peak of the cassava starch (250 RVU), cited by Takizawa et al. (2004), was lower than that found in the present paper for the Peruvian carrot native 
starches (average value of 432 RVU). The differences between the starches from different sources are attributed mainly for the molecular weight of amylose and amylopectin chains and the amylose content. The final viscosity is an important quality indicator for the food use of the starches due to the fact that in most cases this will be the viscosity on the final product that arrives on the consumer's home. If a starch produces high or low viscosity paste, it can be used for different applications.

For the soups, for example, low viscosity starches should be preferred, but for the use as the gelling agent in the pie filling, a high viscosity would be desired for preventing the spilling during the transportation. Other functional properties of great interest for the food industry are the stability to cooking at high temperatures under the stirring and acid conditions (Daiuto, 2005).

\section{Syneresis}

The pastes formed during the cooking of the starch suspensions on excess water are not stable and suffer transformations on cooling and storage that are referred as retrogradation. Starch molecules are rearranged with the formation of a more ordered structure, releasing undesirable water, called syneresis (Atwell et al., 1998). The percentages of the liberated liquid by the starch pastes are shown in Table 6. Parovuori et al. (1995) reported that the highest liquid liberation from the pastes of oxidized starches could be associated with the weak starch structure and lower molecular weight of the starch polymers.

Table 6 - Percentage of liberated liquid during freeze-thawing.

\begin{tabular}{lccc}
\hline \multicolumn{1}{c}{ Sample } & $\mathbf{1}^{\text {st }} \mathbf{C y c l e *}$ & $\mathbf{2}^{\text {nd }} \mathbf{C y c l e}^{*}$ & $\mathbf{3}^{\text {rd }} \mathbf{C y c l e}^{*}$ \\
\hline$A C C$ - native & $10.1 \pm 0.71$ & $49.3 \pm 6.42$ & $70.2 \pm 0.64$ \\
$A C C$ - modified & $43.3 \pm 0.32$ & $74.1 \pm 2.06$ & $75.6 \pm 0.72$ \\
$A C P$ - native & $22.8 \pm 0.36$ & $58.8 \pm 7.51$ & $62.4 \pm 0.21$ \\
$A C P$ - modified & $73.4 \pm 0.00$ & $75.0 \pm 1.62$ & $87.8 \pm 3.31$ \\
$S A P$ - native & $3.70 \pm 0.43$ & $34.4 \pm 8.21$ & $52.7 \pm 0.02$ \\
$S A P-$ modified & $56.7 \pm 1.04$ & $76.9 \pm 2.30$ & $79.1 \pm 1.42$ \\
\hline
\end{tabular}

* each value is the average and deviation of three determinations.

As expected, the liquid liberation increased with the sequence of the freeze-thawing cycles for all the studied samples. There was influence of the way the paste was produced and stored over liquid liberation (Yuan and Thompson, 1993). There was a phase separation and formation of ice crystals during the freeze-thawing. During the thawing, the starch paste was composed of a starch-rich phase and another deficient. This phase separation was evidenced with the sequential freeze-thaw cycles due to the increase of the concentration of the retrograded amylopectin molecules in the aqueous phase rich in the starch. The functional property of presenting the low retrogradation tendency has been related to different starch compounds. The syneresis phenomenon was firstly attributed to the amylose molecules, that re-associate with the inter or intra-molecular hydrogen bonds (Dreher et al., 1983). Hoover and Sosulski (1991) suggested that the syneresis intensity could be associated with the amylose content, degree of starch polymers association, length of amylopectin side chains and amylose and amylopectin degree of polymerization. The methodology of the freezethawing has the objective of simulating what happens during the processing, storage and commercialization of food products. In most cases, the liquid liberation is undesirable and has negative effects on the texture, appearance of sauces, meat products, salad dressings and desserts.

\section{Paste clarity}

The transparency/opacity of starch pastes is an important quality attribute and varies considerably with the botany origin of starch. The results are shown in Table 7 and are in accordance with previously published data (Takizawa et al., 2004). Higher amylose contents produce opaque pastes and lower contents produce clear, transparent pastes. As shown by Moorthy (1994), the starch oxidation results in transparent pastes. The paste clarity was measured as the transmittance at 650 $\mathrm{nm}$. The values for the native starches varied from 38.2 to $47.1 \%$, revealing more opaque pastes. This opacity could be related with the amylose 
content of this starch that was analyzed by Leonel and Cereda (2002) and corresponded to $23 \%$. In the case of the modified starches, the values were higher, from 86.0 to $96.5 \%$ of the transmittance, being considered transparent pastes. This high transparency could be related to the carboxyl groups of the starch molecules and also to the oxidative depolymerisation confirmed by the results of the reducing power values. Craig et al. (1989) reported that the formation of the inter and intra-molecular junction zones resulted in opacity and was probably associated with the amylopectin molecules. They reported $73 \%$ of transmittance at $650 \mathrm{~nm}$ for the native cassava starch, higher than the values of the Peruvian carrot native starch.
Karam (2003) studied cassava, corn and yam starches, and found that the paste clarity could be explained not only by the amylose content but also by the molecular length of amylose that would suffer rapid re-association. The low stability and clarity of amylose solutions are due to easy reassociation of linear chains by the hydrogen bonds. More opaque pastes would be desired for foods like puddings and ready-to-eat desserts (Hoover, 2001), and this characteristic is found on Peruvian carrot native starches. The modified starches, on the other hand, produced the transparent pastes and could be used on the pie fillings, for example.

Table 7 - Paste clarity of Peruvian carrot starches.

\begin{tabular}{cc}
\hline Sample & Paste clarity $(\% \mathbf{T}) *$ \\
\hline$A C C-$ native & $38.2 \pm 2.61$ \\
$A C C-$ modified & $86.0 \pm 0.98$ \\
$A C P$ - native & $41.6 \pm 4.17$ \\
$A C P-$ modified & $86.6 \pm 3.67$ \\
$S A P-$ native & $47.1 \pm 2.82$ \\
$S A P$ - modified & $96.5 \pm 2.12$ \\
\hline
\end{tabular}

* each value represents the average and deviation of three determinations.

\section{Thermal Analysis}

The thermo-gravimetric (TG) and Differential Thermal Analysis (DTA) were employed for studying the native and modified starches of the Peruvian carrot. Deep modifications and structural changes occurred on the starch molecules during the heating. The degree of alterations depends on the temperature and time and in drastic conditions, complete carbohydrate degradation can occur (Aggarwal and Dollimore, 1998). The results are shown in Table 8 and are also illustrated in Figure 4. On the DTA curve, the difference of the temperature between sample and reference was measured $\left(\Delta \mathrm{T}=\mathrm{T}_{\mathrm{s}}-\mathrm{T}_{\mathrm{r}}\right)$ (Ionashiro, 2005). In the case of TG the sample mass (g) was continuously monitored as the function of the temperature $(\mathrm{T})$ or time ( $t$ ). The differences observed on TG curves represented the mass losses and could be quantitatively collected (IONASHIRO, 2005).

Table 8 - TG and DTA curves of the Peruvian carrot starches.

\begin{tabular}{lcccc}
\hline \multicolumn{1}{c}{ Sample } & Moisture $(\%)$ & Onset $\left({ }^{\mathbf{0}} \mathbf{C}\right)$ & Mass loss $(\%)$ & DTG $\left({ }^{\circ} \mathbf{C}\right)$ \\
\hline$A C C$ - native & 8.52 & 295.87 & 88.14 & 310.37 \\
$A C C$ - modified & 11.4 & 290.37 & 87.19 & 294.16 \\
$A C P$ - native & 9.74 & 297.46 & 89.64 & 299.08 \\
$A C P$ - modified & 11.5 & 292.56 & 87.64 & 296.65 \\
$S A P$ - native & 9.57 & 294.59 & 88.75 & 311.18 \\
$S A P$ - modified & 11.3 & 291.22 & 87.73 & 293.29 \\
\hline
\end{tabular}

Onset: initial temperature.

DTG: derivative termogravimetry. 


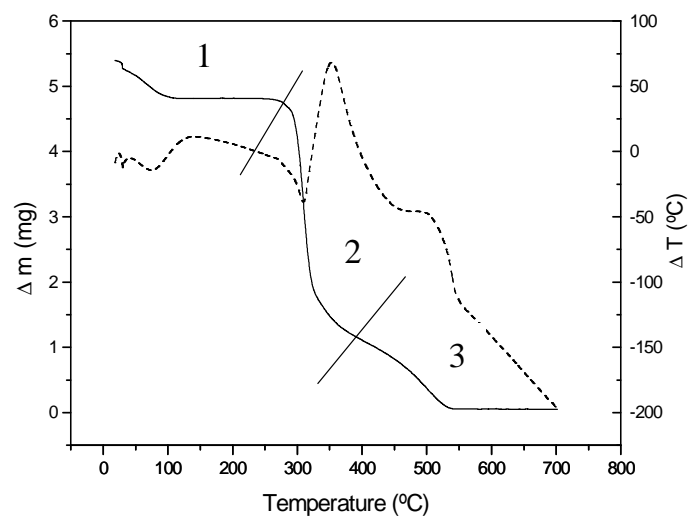

Figure 4 - TG and DTA curves of the native starch of the variety Amarela de Carandaí /Castro.

As described by Soliman et al. (1997), three distinct regions are observed on the TG curves: 1) the region below $150{ }^{\circ} \mathrm{C}$ that represents the evaporation of the water and of other volatile compounds; 2) the principal region of degradation; $3)$ the region of propagation reaction. These regions were quantified (Table 8). The moisture represented the first mass loss, between 100 and $150{ }^{\circ} \mathrm{C}$. The onset was considered the tangent of the TG curve being calculated and presented in Table 8. Higher onset temperatures were found for the native than for the modified starches. Soliman et al. (1997) studied the native and potassium permanganate-modified corn starches and also found higher onset temperatures for the native $\left(275^{\circ} \mathrm{C}\right)$ than for the modified samples $(250,237$, $230{ }^{\circ} \mathrm{C}$ ). This temperature was considered as the initial pyrolysis of the starch molecules.

The results, as also described by Soliman et al. (1997), suggested that the oxidized starches were more sensitive to the thermal degradation. The mass loss showed in Table 8 occurred in the temperature range of $150-600{ }^{\circ} \mathrm{C}$ and was higher for the native starches than for the modified ones. Aggarwal and Dollimore (1998), studying the partial hydrolysis of the corn starch, described the polyhydroxyl groups elimination reactions, concomitant to the depolymerization and degradation of the starch. In the DTG, the derivative of the mass loss $(d \mathrm{~m} / d \mathrm{t})$ is plotted as a function of temperature or time. The curves are the first derivative of the TG data and indicate the temperatures in which the degradation processes start and that where the reaction maximum velocity is reached (Ionashiro, 2005). These DTG curves are shown in Table 8 . The temperatures of the native starches $\left(310.37,299.08,311.18{ }^{\circ} \mathrm{C}\right)$ were higher than that of the modified (294.16, 296.65, 293.29 ${ }^{\circ} \mathrm{C}$ ). Aggarwal and Dollimore (1998) concluded that due to the high superficial area of the partial hydrolysed starches, it was possible to explain their lower degradation temperatures when studied by thermal analysis. Soliman et al. (1997) comparing the native and oxidized starches noted that the activation energy changes were due to the carboxyl content of the modified samples. Their carboxyl results for the native and oxidized corn starches were comparable to the data found for the Peruvian carrot starches.

\section{AKNOWLEDGEMENTS}

The authors are grateful to the Conselho Nacional de Desenvolvimento Científico e Tecnológico $(\mathrm{CNPq})$ and Fundação Araucária for the financial support.

\section{RESUMO}

No presente trabalho duas variedades comerciais de mandioquinha-salsa ('Amarela de Carandaí' e 'Senador Amaral') obtidas dos municípios de Castro e de Piraí do Sul (Paraná) foram processadas para a obtenção de farinha, farelo e amido e essas três frações foram caracterizadas quimicamente. $\mathrm{O}$ amido foi extraído, modificado com $\mathrm{H}_{2} \mathrm{O}_{2}$ e caracterizado por meio de análises físico-químicas. Na coloração com azul de metileno os grânulos dos amidos oxidados apresentaram coloração azul mais intensa. O teor 
de carboxilas, o poder redutor e a quantidade de água liberada das pastas foram maiores para as amostras de amidos modificados. As pastas dos amidos modificados foram mais claras que as dos nativos. $\mathrm{Na}$ análise viscoamilográfica (RVA) os amidos modificados apresentaram as menores viscosidades e houve diferenças entre as variedades, sendo que o amido modificado da variedade Senador Amaral de Piraí do Sul apresentou os menores valores de pico de viscosidade. $\mathrm{Na}$ análise térmica, as temperaturas de pirólise foram mais altas para os amidos nativos das variedades da mandioquinha-salsa $(310,37$, 299,08, 311,18 ${ }^{\circ} \mathrm{C}$ ) do que para os amidos modificados $\left(294,16,296,65\right.$ e $\left.293,29^{\circ} \mathrm{C}\right)$ e esta diferença pode estar relacionada a maior superfície dos grânulos de amido parcialmente degradados pela modificação oxidativa. Os resultados revelaram diferenças entre os amidos das duas variedades, mas não entre os locais de cultivo.

\section{REFERENCES}

Aggarwal, P.; Dollimore, D. (1998), A thermal analysis investigation of partially hydrolyzed starch. Thermochimica Acta, 319, 17-25.

AOAC (1994), Association of Official Analytical Chemists. Official Methods of Analysis. 12 ed. Washington.

AOAC. (1997) Association of Official Analytical Chemists. Official Methods of Analysis. 13 ed. Washington.

Asaoka, M.; Blanshard, J. M. V; Rickard, J. E. (1992), The effects of cultivar and growth season on the gelationisation properties of cassava (Manihot esculenta) starch. J. Sci. Food Agric., 59, 53-58.

Atwell,W. A.; Hood, L. F.; LINEBACK, D. R.(1998), The terminology and methodology associated with basic starch phenomena. Cereal Foods World, 33, 306-311.

Bermudez, J. J. H. (1997), Valorización de las amilaceas "no-cereals" cultivadas en los países andinos: estudio de las propriedades fisicoquimicas y funcionales de sus almidones y de la resistencia a diferentes tratamientos estresantes. Trabajo de Grado, Facultad de Ingeniería de Alimentos, Universidad de Bogotá, Colombia.

Câmara, F. L. A.; Santos, F. F. (2002) Cultura da mandioquinha-salsa. In: CEREDA, M.P. Agricultura: Tuberosas Amiláceas Latino Americanas. São Paulo: Fundação Cargill, 2, pp.519-532.
Cereda, M. P.; Vilpoux, O. F.; Demiate, I. M. (2003), Amidos modificados. In: CEREDA, M. P.; VILPOUX, O.F. Tecnologia, usos e potencialidades de Tuberosas Amiláceas Latino Americanas. São Paulo: Fundação Cargill, 3, pp. 246-332.

Ciacco, C. F. et al. (1982), Fabricação de amido e sua utilização. São Paulo: Secretaria de Indústria e Comércio, Ciência e Tecnologia, 152 pp. (Tecnologia Agroindustrial, 7).

Craig, S. A. S.; Maningat, C. C.; Seib, P. A.; Hoseney, R.C. (1989), Starch Paste Clarity. Cereal Chemistry, 66, 173-182.

Christianson, D. D., Nielson, H. C., Khoo, V., Woff, M. J., Wall, J. S. (1969), Isolation and chemical composition of protein bodies and native proteins in corn endosperm. Cereal Chemistry, 46, 372-381.

Dahlquist, A. (1961), Determination of maltase and isomaltase activities with a glucose oxidase reagent. Biochemical Journal, 8, 547-551.

Daiuto, E. R. (2005), Características de féculas de tuberosas e suas relações com resistências dos géis sob condições de estresse aplicada na industrialização de alimentos. Tese de Doutorado, Universidade Estadual Paulista, Botucatu, Brasil.

Demiate, I. M. (1999), Desenvolvimento de fécula de mandioca auto-expansível. Tese de Doutorado, Faculdade de Ciências Agronômicas, Universidade Estadual Paulista, Botucatu, Brasil.

Demiate, I. M.; Konkel, F. E.; Pedroso, R. A. (2001), Enzymatic determination of starch in Doce de Leite using dialysis. Ciência e Tecnologia de Alimentos, Campinas, 21, 339-342.

Demiate, I. M.; Oetterer, M.; Wosiacki, G. (2001), Characterization of chestnut (Castanea sativa, Mill) starch for industrial utilization. Brazilian Archives of Biology and Technology, 44, 69-78.

Demiate, I. M.; Wosiacki, G.; Cereda, M. P.; Mestres, C. (2005), Viscographic characteristics of chemically modified cassava starches assessed by RVA. Publicatio UEPG, 11, 7-17.

Dias, A. R. G. (2001), Efeito de oxidantes, de ácidos orgânicos e da fração solúvel em água na propriedade de expansão do amido de mandioca fermentado. Tese de Doutorado, Universidade Estadual de Campinas, Campinas, Brasil.

Dreher, M. I.,et al. (1983), Buffalo gourd root starch. II. Rheologic behaviour, freeze-thaw stability for use in food products. Starch/Stärke, 35, 157-162.

Franco, C.M.L. et al. (2002), Structural characteristics and functional properties of wheat starches. Cereal Chemistry, 79, 243-248.

Hashim, D. B. et al. (1992), The effect of low levels of antioxidants on the swelling and solubility of cassava starch. Starch/Stärke, 44, 471-475. 
Hoover, R.; Sosulski, F. W. (1991), Composition, structure, functionality and chemical modification of legume starches: a review. Canadian Journal of Physiology and Pharmacology, 69, 72-79.

Hoover, R. (2001), Composition, molecular structure, and physicochemical properties of tuber and root starches: a review. Carbohydrate Polymers, 45, 253267.

Hurtado, J. et al. (1997), Procesamiento de la arracacha (Arracacia xanthorrhiza): Estudio de la factibilidad técnica y económica para la producción de almidón y harina y sus propiedades fisicoquímicas. Seminario Técnico sobre Raíces y Tubérculos autóctonos, 27-29 mayo, Ibagué, Colombia.

International Starch Institute. (2005), Determination of reductive power in starch. Available in: http://home3.inet.tele.dk./starch/isi/methods/35rcu.ht m. Access: May 3rd, 2005.

Ionashiro, M. (2005), Giolito: Fundamentos da Termogravimetria e Análise Térmica Diferencial/Calorimetria Exploratória Diferencial, Giz Editora, São Paulo. 80 pp.

Jane, et al. (1999), Effects of amylose branch chain length and amylose content on the gelatinization and pasting properties of starch. Cereal Chemistry, 76, 629-637.

Karam, L. B. (2003), Propriedades funcionais de multimisturas de amidos de milho, mandioca e cará e sua relação com as características físicas e moleculares. Tese de Doutorado, Universidade Estadual de Londrina, Londrina, Brasil.

Kuakpetoon, D.; Wang, Y.-J. (2006) Structural characteristics and physicochemical properties of oxidized corn starches varying in amylose content. Carbohydrate Research, 341, 1896-1915.

Leach, H. W.; Mccowen, L. D.; Schoch, T. J. (1959), Structure of starch granule. I. Swelling and solubility patterns of various starches. Cereal Chemistry, 36, 534-544.

Leonel, M.; Cereda, M. P. (2002), Caracterização físico-química de algumas tuberosas amiláceas. Ciência e Tecnologia de Alimentos, 22, 65-69.

Mattisson, M. F.; Legendre, K. A. (1952) Determination of the Carboxyl Content of Oxidized Starches. Anal. Chem., 24, 1942-1944.

Moorthy, S. N. (1994), Tuber Crop Starches. Thiruvananthapuram : Central Tuber crops research institute, 40 pp. (Technical Bulletin Series, v.18).

Muhrbeck, P.; Wischmann, B. (1998), Influence of phosphate ester on the annealing properties of starch. Starch/Stärke, 50, 423-426.

Parovuori, P. et al. (1995), Oxidation of potato starch by hydrogen peroxide. Starch/Stärke, 47, 19-23.

Pereira, A.S. (1997), Valor Nutritivo da mandioquinhasalsa. Informe Agropecuário, 19, 11-12.
Peroni, F. H. G. (2003), Características estruturais e físico-químicas de amidos obtidos de diferentes fontes botânicas. Dissertação de Mestrado, Universidade Estadual Paulista "Julio de Mesquita Filho", São José do Rio Preto, Brasil.

Sarmento, S.B.S. (1997), Caracterização da fécula de mandioca (Manihot esculenta) no período de colheita de cultivares de uso industrial. Tese de Doutorado, Faculdades de Ciências Farmacêuticas, Universidade de São Paulo, São Paulo, Brasil.

Smith, R. J. (1967), Characterization and analysis of starches. In: Whistler, R.L.; Paschall, E.F. (Eds.), Starch: Chemistry and Technology, 2, New York: Academic Press, pp.569-635.

Snyder, E. M. (1984), Industrial microscopy of starches. In: WHISTLER, R.L. BEMILLER, J.N. PASCHALL, E.F. (eds). Starch: Chemistry and Technology, $2^{\text {nd }}$ ed., New York: Academic Press, pp.575-591.

Soliman, A. A. A, El-Shinnawy, N. A., Mobarak. (1997), Thermal behaviour of starch oxidized starch. Thermochimica Acta, 296, 149-153.

Takizawa, F. F.; Silva, G. O.; Konkel, F. E.; Demiate, I. M. (2004), Characterization of tropical starches modified with potassium permanganate and lactic acid. Brazilian Archives of Biology and Technology, 47, 921-931.

Vieira, F. C. (2004), Efeito do tratamento com calor e baixa umidade sobre características físicas e funcionais dos amidos de mandioquinha-salsa (Arracacia xanthorrhiza), de batata-doce (Ipomoea batatas) e de gengibre (Zingiber offinale). Dissertação de Mestrado, Escola Superior de Agricultura "Luiz de Queiroz", Universidade de São Paulo, Piracicaba, Brasil.

Wosiacki, G.; Cereda, M; P. (1985), Characterization of pinhão starch. Starch/Stärke, 37, 224-227.

Yuan, R.C.; Thompson, D.B. (1993), Fine structure of amylopectin in relation to gelatinization and retrogradation behavior of maize starches from three wx-containing genotypes in to inbread lines. Cereal Chemistry, 75, 81-89.
Received: June 13, 2006; Revised: March 23, 2007; Accepted: July 20, 2008. 